\begin{tabular}{|l|l|l||}
\hline \multicolumn{2}{|c|}{ PublisherInfo } \\
\hline \hline PublisherName & $:$ & BioMed Central \\
\hline \hline PublisherLocation & $:$ & London \\
\hline \hline PublisherImprintName & $:$ & BioMed Central \\
\hline \hline
\end{tabular}

\title{
Human effector CD4 T cells: less is more?
}

\begin{tabular}{||l|l|l||}
\hline \multicolumn{2}{|c||}{ ArticleInfo } \\
\hline \hline ArticleID & $:$ & 59 \\
\hline \hline ArticleDOI & $:$ & $10.1186 /$ ar-2001-71050 \\
\hline \hline ArticleCitationID & $:$ & 71050 \\
\hline \hline ArticleSequenceNumber & $:$ & 16 \\
\hline \hline ArticleCategory & $:$ & Paper Report \\
\hline \hline ArticleFirstPage & $:$ & 1 \\
\hline \hline ArticleLastPage & $:$ & 3 \\
\hline \hline & & RegistrationDate $: 2001-8-20$ \\
ArticleHistory & $:$ & Received \\
& Accepted 2001-8-20 \\
\hline \hline ArticleCopyright & $:$ 2001-9-13 \\
\hline \hline ArticleGrants & $:$ & Biomed Central Ltd2001 \\
\hline \hline
\end{tabular}




\begin{tabular}{|l|l|l|}
\hline ArticleContext & $:$ & 130753311 \\
\hline
\end{tabular}

$\underline{\text { Birgit Kovacs, }}{ }^{\text {Aff1 }}$

Aff1 University of Pennsylvania, Philadelphia, PA, USA

\section{Keywords}

CD3?, CD4 ${ }^{+}$T lymphocytes, immunology, phosphorylation, $\mathrm{T}$ lymphocytes

\section{Context}

Activation of naive $\mathrm{T}$ cells and their subsequent differentiation into effector cells - which orchestrate immune mediated antigen challenge - are essential for the initiation of adaptive immune responses. This differentiation occurs over a period of several days and not much is known about the biochemical events associated with the differentiation process. The study of human effector $\mathrm{T}$ cells has been especially difficult as they are difficult to isolate ex vivo and to distinguish from resting memory $\mathrm{T}$ cells and naive $\mathrm{T}$ cells. In this study, the authors generated human CD4 effector cells and studied their biochemical properties in vitro.

\section{Significant findings}

The authors generated human effector CD4 T cells by first using a two-step immunodepletion procedure. The resulting naive CD4 $\mathrm{T}$ cells were activated with anti-CD3 antibody for several days in the presence of purified autologous peripheral blood mononuclear cells to produce effector $\mathrm{T}$ cells. The resulting cells produced high levels of IFN? and expressed the activation markers CD25 and CD69. In contrast to naive cells, the effector T cells were also characterized by large size. Following CD3 crosslinking, there was increased phosphorylation of several protein species in the effector cells compared to naive cells. However, there was a marked absence of phosphorylated CD3?, an $18 \mathrm{kDa}$ protein, in the effector cells; the deficiency was thought to be due to a decreased CD3?, but was not due to decreased transcription. In the effector CD4 cells CD3e was also downregulated whereas the level of ZAP70 was not decreased. The authors show that human effector $\mathrm{T}$ cells can be generated in vitro and can be distinguished biochemically from naive $\mathrm{T}$ cells. 


\section{Comments}

This paper is intriguing because it shows that, despite downregulation of molecules thought to be essential for signal transduction in human T cells, activation of effector cells can be achieved. It will be important to establish whether the loss of CD3? is due to increased degradation of the protein and whether CD3? is replaced in human effector cells by other signaling molecules such as FceRI?, as has been shown previously in mice. Decreased CD3? expression has been identified in many disease states, including systemic lupus erythematosus, rheumatoid arthritis, HIV and cancer and it will be interesting to determine whether these disease-associated cell populations represent effector $\mathrm{T}$ cells generated as a result of chronic immune activation.

\section{Methods}

Cell culture, FACS analysis, western blot, RT-PCR

\section{Additional information}

Data about FceRI?/CD3? complexes in mice can be found in the following article:

Ardouin L, Boyer C, Gillet A, Trucy J, Bernard AM, Nunes J, Delon J, Trautmann A, He HT, Malissen B, Malissen M: Crippling of CD3-? ITAMs does not impair T cell receptor signaling. Immunity 1999, 10:409-420 (PubMed abstract).

Others have shown that human effector CD4 T cells also upregulate the transcription factor NFAT1:

Cron RQ, Bort SJ, Wang Y, Brunvand MW, Lewis DB: T cell priming enhances IL-4 gene expression by increasing nuclear factor of activated T cells. $J$ Immunol 1999, 162:860-870 (PubMed abstract).

\section{References}

1. Krishnan S, Warke VG, Nambiar MP, Wong HK, Tsokos GC, Farber DL: Generation and biochemical analysis of human effector CD4 T cells: alterations in tyrosine phosphorylation and loss of CD3? expression. Blood. 2001, 97: 3851-3859. 